\title{
INDUSTRIAL ZONING OF EAST AZERBAIJAN PROVINCE OF IRAN USING MULTICRITERIA EVALUATION MODELING
}

\author{
NAGHDI, F. ${ }^{1}$ - MONAVVARI, S. M. ${ }^{1 *}-$ HOSSEINI, S. M. ${ }^{2}$ - GHARAGOZLU, A. ${ }^{1}$ \\ ${ }^{I}$ Department of Environmental Science, Faculty of Environment and Energy, Tehran Science \\ and Research Branch, Islamic Azad University, Tehran, Iran \\ ${ }^{2}$ Department of Forestry, Faculty of Natural Resources, Tarbiat Modares University, Noor, \\ Mazandaran, Iran \\ *Corresponding author \\ e-mail:monavarism@yahoo.com \\ (Received $7^{\text {th }}$ Dec 2016; accepted $9^{\text {th }}$ Mar 2017)
}

\begin{abstract}
Industrialization potential and industrial zoning dependence on bioenvironmental conditions have been under special research focus. Having analyzed national and global standards and models, 22 ecological and human related parameters affecting industrial zoning were selected and evaluated. Then, information layers and digital maps were generated. The layers were statistically analyzed and compared within evaluation models of WLC, SAW and TOPSIS to determine each model's sensitivity in industrial zoning. Zoning outcomes by different evaluation models demonstrated that sensitivity to ecological parameters were different among the models. The three models diagnosed differing regional areas that were suitable for industrialization. The statistical comparisons of different categories among the evaluation models showed that the total areas suitable for industrialization varied by model. The total areas suitable for industrial development obtained by TOPSIS method was less than that found by WLC and SAW methods. This was due to prioritizing human related factors in weighing different parameters for industrial zoning by TOPSIS vs. WLC and SAW. Despite the models' differences in the total area suitable for industrialization, the types of areas were widely common among the models. In all models, Myaneh, Shabestar and Charoymagh regions were specified to be suitable for industrialization. It is implied that the above regions should be given priority in policy-making and future investment programming for industrial expansion. Such a priority stems from specific ecological, social and economic properties, their current industrial infrastructures, and suitable population density in these regions.
\end{abstract}

Keywords: evaluation model; multicriteria analysis; ecology; industry; Iran

\section{Introduction}

Effective management of natural, human, and economic resources for industrial development requires multidisciplinary bioenvironmental and zoning considerations (Ruiz Puente et al., 2007). Industrial site selection and zoning is a multicriteria decisionmaking process (Atthiawong and MacCarthy, 2002). The land zoning procedures are conducted using multicriteria evaluation methods that are based on Fuzzy algorithms and logics (Geneletti and van Duren, 2008; Store, 2009). Evaluation and capability assessment methods such as Fuzzy OWA (Malczewski, 2006), combined WLC and AHP (UP\&ARCI, 2000) and TOPSIS (Kazemi Rad et al., 2012) are widely recognized and commonly used in site selection and industrial zoning programs. For instance, combinations of AHP-TOPSIS (Chang et al., 2012) and AHP-WLC (Hosseini et al., 2009; Monavvari et al., 2013; Naghdi et al., 2011; Raeesi and Safianian, 2011; Ranjbar and Naghdi, 2013; Naghdi and Nikkhah, 2014) have been used in coasts bioenvironmental protection and site selection for lands with industrial, agricultural and 
urban applications. In addition, TOPSIS (Lee, 2013; Kazemi Rad et al., 2012), Fuzzy (Jiang and Eastman, 2000), and Fuzzy-TOPSIS (Alavi and Alinejad-Rokny, 2011; Aryanezhad et al., 2011; Mokhtarian and Hadi-Vencheh, 2012; Yayla et al., 2012) methods have been applied to evaluate flood risk and land zoning for different industries such as power plans, mines and garments, manufactures, and bridge risk assessment.

East Azerbaijan as an important province (45490.88 square $\mathrm{km}$ area) in northwest Iran is host to enormous industries and manufactures that are mostly located around the capital populated city of Tabriz. The province contributes by $7.44 \%$ to Iran's industrial added value and by $13.13 \%$ to national GDP (Statistical Yearbook of East Azerbaijan, 2006). However, industrial land use and development have been in many cases scientifically and ecologically suboptimal. The province has been encountering increasing environmental pollutions; while no major inclusive and decisive industrial zoning research based on already recognized global methods has been conducted. Therefore, the objective of this study was to establish, for the first time, site selection and industrial zoning on the basis of ecological and nonecological parameters.

\section{Materials and Methods}

\section{Study area}

This study was conducted in the northwestern Iranian province of East Azerbaijan, an economically and environmentally important and relatively densely populated region. The province is located in $45^{\circ} 7^{\prime}$ to $48^{\circ} 20^{\prime}$ East and $36^{\circ} 45^{\prime}$ to $39^{\circ} 26^{\prime}$ North, with an area equal to 45846.572 square kilometers (approximately $2.81 \%$ of total country area) (Khorshiddoost et al., 2007). East Azerbaijan is a mountainous area with $40 \%$ of its surface being high mountains, $28.2 \%$ foothills, and $31.8 \%$ intermountain plains (Figure 1).

\section{Research methodology}

1. Library and field studies and documentations

2. Delphi questionnaire and interviews

3. Statistical and locational analyses

\section{Research procedures and processes}

Establishing the criteria affecting industrial zoning

Numerous parameters must be taken into account in industrial zoning programs (Mokhtarian and Hadi-Vencheh, 2012; Yu and $\mathrm{Hu}, 2010$ ). To establish the influential criteria and indices for industrial site selection, a questionnaire was developed according to Delphi methodology. In addition, complementary criteria were determined based on widely accepted national and international standard models of industrial placing. After determining the foremost criteria, specialized bioenvironmental maps were generated using Remote Sensing (RS) and Geographical Information System (GIS) programs. These programs were used for statistical data analysis, satellite images processing, potential evaluation, and land zoning. 


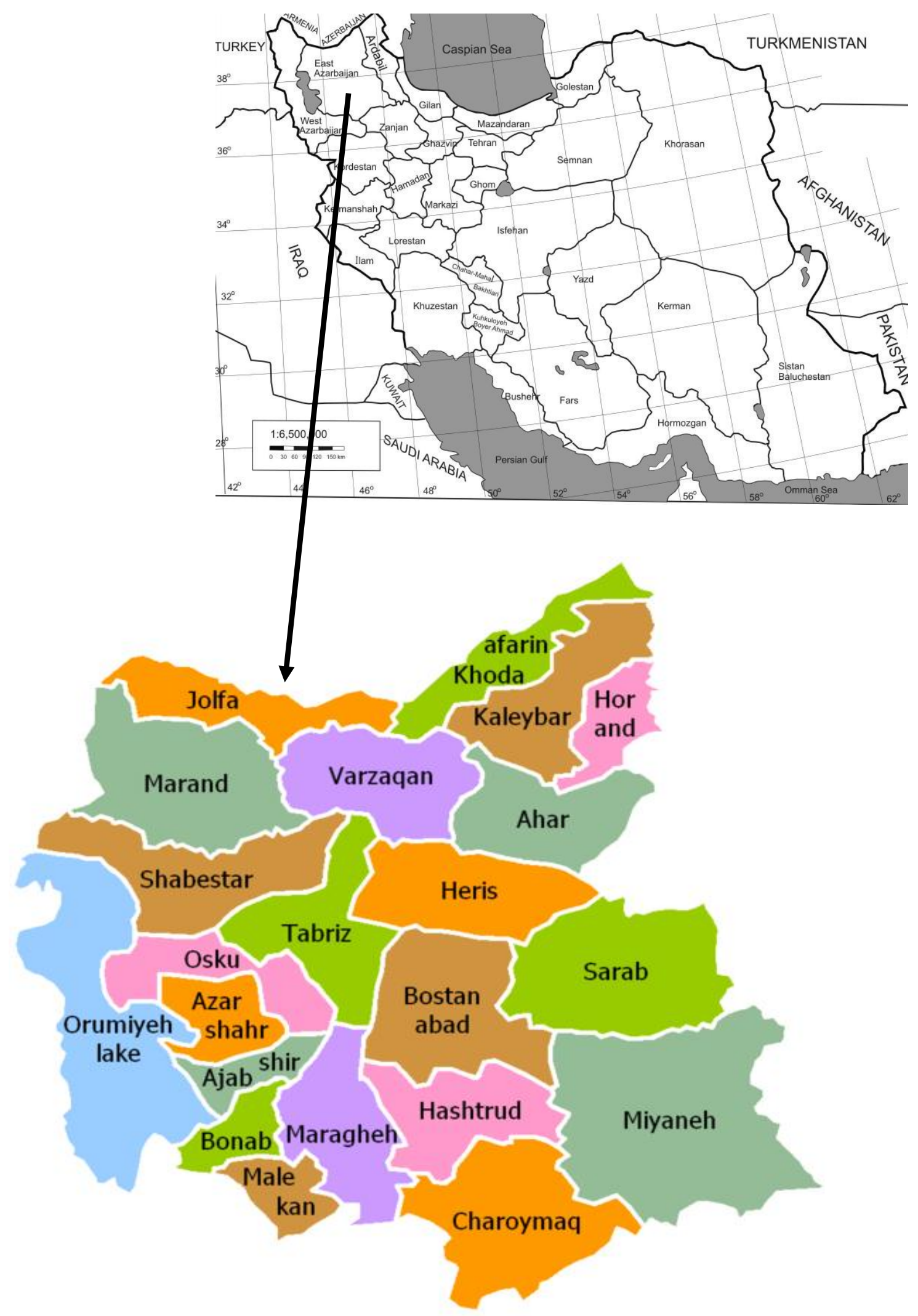

Figure 1. Location of the study area in the country. 
A total of 22 evaluation criteria (information layers) for site selection and industrial zoning were finalized. These consisted of ecological and nonecological (human functions related) parameters including erosion sensitivity, soil depth, soil texture, climate, altitude ,slope, aspect, stone, distance from fault, distance from permanent rivers and permanent aqueduct, distance from deep and semi-deep wells, vegetation density, distance from protected areas, distance from cities, distance from villages, distance from water lines, distance from power lines, distance from existent industrials, distance from airport, distance from main roads and highways, land use planning, population density.

\section{Site selection analysis}

On the basis of the data collected, multicriteria analyses were conducted to order the parameters based on their degree of importance for decision-making in the provincial site selection for industrialization. To optimally combine the information layers and make multicriteria decisions, the Weighted Linear Combination (WLC; Burrough, 1990), Simple Additive Weighting (SAW; Eastman, 1997) and the Technique for Order of Preference by Similarity to Ideal Solution (TOPSIS; Chen, 2000; Wang and Elhag, 2006) algorithms were utilized. These methods and models are founded on the weight means concept. Briefly, the order of preference for each evaluation parameter or criterion was calculated by multiplying the weight of relative importance that is allocated in the model by the known scaling standard for that parameter (Parhizgar and Ghafari Gilandeh, 2006). Next, the parameters were ordered based on their final scaled value that was the sum of the above-mentioned products (Jozi and Saffariyan, 2011).

\section{Study stages}

\begin{tabular}{l}
$\begin{array}{l}\text { Defining and determining the evaluation criteria based on } \\
\text { the questionnaire completed using the Delphi method, } \\
\text { digitalizingthe data and information with AutoCAD software }\end{array}$ \\
\begin{tabular}{|l|l|}
\hline Making the criteria maps and data standard \\
SAW methods
\end{tabular} \\
\hline $\begin{array}{l}\text { Zoning for industries establishment by TOPSIS, WLC, SAW } \\
\text { methods }\end{array}$ \\
\hline \begin{tabular}{|l|l|} 
Industrial Potential Evaluation according to WLC,SAW,TOPSIS \\
models
\end{tabular}
\end{tabular}




\section{Criteria standardization using Fuzzy method}

The evaluation criteria for industrial zoning were selected and finalized based on nationally and internationally recognized standards. These standards included EPA, Guidelines On Sustainable Industrial Zone, Guidelines for Siting of Industry, Industrial Park Site Selection, UNEP, GIS, Zoning Atlas of India, Makhdoom Ecological Model, Iranian Organization of Environmental Protection, Iranian Food and Drug Deputy: Health Rules, Atthiawong and MacCarthy (2002), Monavvari et al. (2013), Raghu Babu (2002), Gupta (2005), Dudukovic et al. (2005), Jiang (2007), Eldin and Eldrandly (2004), Church (2002).

The standard maps (layers) generated for all evaluation parameters were optimized using Idrisi Software (Alizadeh et al., 2013). Then, the maps were co-scaled to be comparable with each other (Sui, 1999). The threshold limit (TL) and the type of Fuzzy function (Bellman and Zadeh, 1977; Zadeh, 1975 )used for layers standardization are given in Table 1 (EPA, 1999; UNEP, 1997; GEUFP, 2007).

Table 1. Threshold limit and type of Fuzzy function used for maps standardization within Fuzzy logic method

\begin{tabular}{|c|c|c|c|c|}
\hline \multirow[b]{2}{*}{ Map layer } & \multicolumn{2}{|c|}{ Threshold limit } & \multirow{2}{*}{$\begin{array}{l}\text { Name of } \\
\text { Fuzzy } \\
\text { function }\end{array}$} & \multirow{2}{*}{$\begin{array}{l}\text { Type of Fuzzy } \\
\text { function }\end{array}$} \\
\hline & $\mathrm{a}, \mathrm{b}, \mathrm{c}$ & $\mathrm{d}$ & & \\
\hline Slope & 1 & 20 & Sigmodial & Decreasing \\
\hline $\begin{array}{l}\text { Distance from main roads and } \\
\text { highway }(\mathrm{m})\end{array}$ & 250 & 5000 & Sigmodial & Increasing \\
\hline Distance from surface water (m) & 1000 & 2500 & Sigmodial & Linear- Increasing \\
\hline Distance from Airport (km) & 5 & 10 & J-shape & Increasing \\
\hline Distance from Well (m) & 100 & 1000 & Sigmodial & Increasing \\
\hline Distance from power lines (m) & 250 & 2000 & Sigmodial & Increasing \\
\hline Distance from Fault $(\mathrm{km})$ & 2 & 10 & J-shape & Linear- Increasing \\
\hline Ston $^{1}$ & 1 & 5 & None & Increasing \\
\hline Altitude (m) & 400 & 1800 & Sigmodial & Decreasing \\
\hline Land use Planning $^{2}$ & 1 & 5 & None & Increasing \\
\hline Aspect $^{3}$ & 1 & 5 & None & Decreasing \\
\hline Soil texture ${ }^{4}$ & 0 & 1 & None & None \\
\hline Soil depth (m) & 30 & 180 & J-shape & Increasing \\
\hline Soil erosion 5 & 0 & 1 & None & Increasing \\
\hline Vegetation density & 5 & 75 & J-shape & Decreasing \\
\hline Distance from protected areas ${ }^{6}$ & 0 & 1 & Linear & Increasing \\
\hline Climate $^{7}$ & 0 & 1 & None & Increasing \\
\hline Distance from Cities (m) & 1500 & 5000 & Linear & Linear- Increasing \\
\hline Distance from Villages (m) & 1500 & 2000 & Linear & Linear-Increasing \\
\hline Reservoirs of water transfers (m) & 1000 & 8000 & Sigmodial & Increasing \\
\hline Distance from Existent Industrials (m) & 250 & 1000 & Sigmodial & Decreasing \\
\hline Population & 50000 & 1000000 & J-shape & Increasing \\
\hline
\end{tabular}

${ }^{1}$ Score 1: Sandstone, and basalt flows, alluvialsediment (alluvial continental shelf); Score 0-1: limestone, clay, granite, fractured tuffs, less stone; Score 0:Marn or Marn layers beneath the rock, seismicity, schist, sand dunes and floodplains.

${ }^{2}$ Score 1: Salt marsh and pasture land, wasteland and semi-intensive low-density;Score 0-1:Agriculture without Water, Forest with low density; Score 0: forests and Pastures with high density, Agriculture to Water, river and city center.

${ }^{3}$ Score 1: Flat and South; Score 0-1: East, West, North.

${ }^{4}$ Score 1: Loam, loam - clay ; Score 0-1: Deep sand, sandy loam shallow to deep, loam and clay loam shallow to Average depth ; Score 0: Shallow sandy, Heavy clay, Soil Hydromorphic.

${ }^{5}$ Score 1: Erodible<5\%; Score 0-1: Erodible 5-70; Score 0: Erodible $>70 \%$.

${ }^{6}$ Score 1: Distance from protected areas $>1 \mathrm{KM}$; Score 0-1: Distance from protected areas $150 \mathrm{M}-1 \mathrm{KM}$; Score 0 : in the protected areas.

${ }^{7}$ Score 0: Tornado path and Mousemi winds; Score 0-1: the rest. 


\section{Weighing procedures}

After the evaluation criteria for industrialization were converted to comparable and standard scales, their weight and relative importance to industrial zoning were determined. This was accomplished using the Analytic Hierarchy Process (AHP), Simple Additive Weighting (SAW), and TOPSIS algorithm procedures (Table 2).

Table 2. Relative weight of evaluation criteria using different weighting methods

\begin{tabular}{clccc}
\hline $\mathrm{N}$ & Criteria & $\begin{array}{c}\text { Standardized } \\
\text { weight }\end{array}$ & SAW & AHP \\
\cline { 2 - 5 } 1 & Erosion Sensivity & 0.0512 & 3.4 & 0.063 \\
2 & Soil Depth & 0.0512 & 3.4 & 0.060 \\
3 & Soil Texture & 0.03719 & 6 & 0.063 \\
4 & Climate & 0.05356 & 3 & 0.035 \\
5 & Altitude (meter) & 0.045 & 4.5 & 0.047 \\
6 & Slope (\%) & 0.03333 & 6.8 & 0.066 \\
7 & Aspect & 0.04074 & 5.3 & 0.054 \\
8 & Stone & 0.03475 & 6.5 & 0.063 \\
9 & Distance from Fault & 0.04890 & 3.8 & 0.0382 \\
10 & Distance from permanent rivers and & 0.03719 & 6 & 0.057 \\
& permanent Aqueduct & & & \\
11 & Distance from Deep and Semi-deep & 0.03719 & 6 & 0.047 \\
& Wells & 0.04338 & 4.8 & 0.040 \\
12 & Vegetation Density & 0.04777 & 4 & 0.041 \\
13 & istance from protected areas & 0.04777 & 4 & 0.034 \\
14 & istance from Cities & 0.04777 & 4 & 0.034 \\
15 & Distance from Villages & 0.03240 & 7 & 0.031 \\
16 & Distance from water lines & 0.05356 & 3 & 0.031 \\
17 & Distance from power lines & 0.05356 & 3 & 0.028 \\
18 & Distance from Existent Industrials & 0.05658 & 2.5 & .0 .25 \\
19 & Distance from Airport & 3 & 0.028 \\
20 & Distance from main roads and & 0.05658 & 5.5 & 0.043 \\
& highways. & 4 & 0.06 \\
21 & Land use Planning & 0.03971 & & \\
22 & Population Density & 0.05356 & & \\
\hline
\end{tabular}

\section{Results and Discussion}

Findings, as presented in Figures 2-4, demonstrated that the total area being suitable and highly suitable for industrialization (categories 4 and 5) was different among the three methods of site selection (i.e., WLC, SAW, TOPSIS). According to ANOVA outputs, the total area being unsuitable for industrialization (category 1) was significantly different among the methods. This occurred since the methods assigned different weights to all the environmental parameters utilized in the evaluation.

The means comparisons specified that TOPSIS and SAW methods differed in the total area evaluated to be unsuitable for industrialization $(\mathrm{P}<0.05)$. However, these two methods were not different in other industrial zone categories. The total area that was decided to be suitable and highly suitable for industrialization was lower in WLC and SAW than in TOPSIS. The main reason for this finding was the greater importance of ecological factors such as water resources, regional slope, and soil texture in the evaluation procedures of WLC and SAW. East Azerbaijan's landscape is usually considered suboptimal in terms of some ecological properties (e.g., physical properties). 
As such, since WLC and SAW give higher weights to these physical properties, the total area calculated to be suitable for industrialization was lower in WLC and SAW vs. TOPSIS.
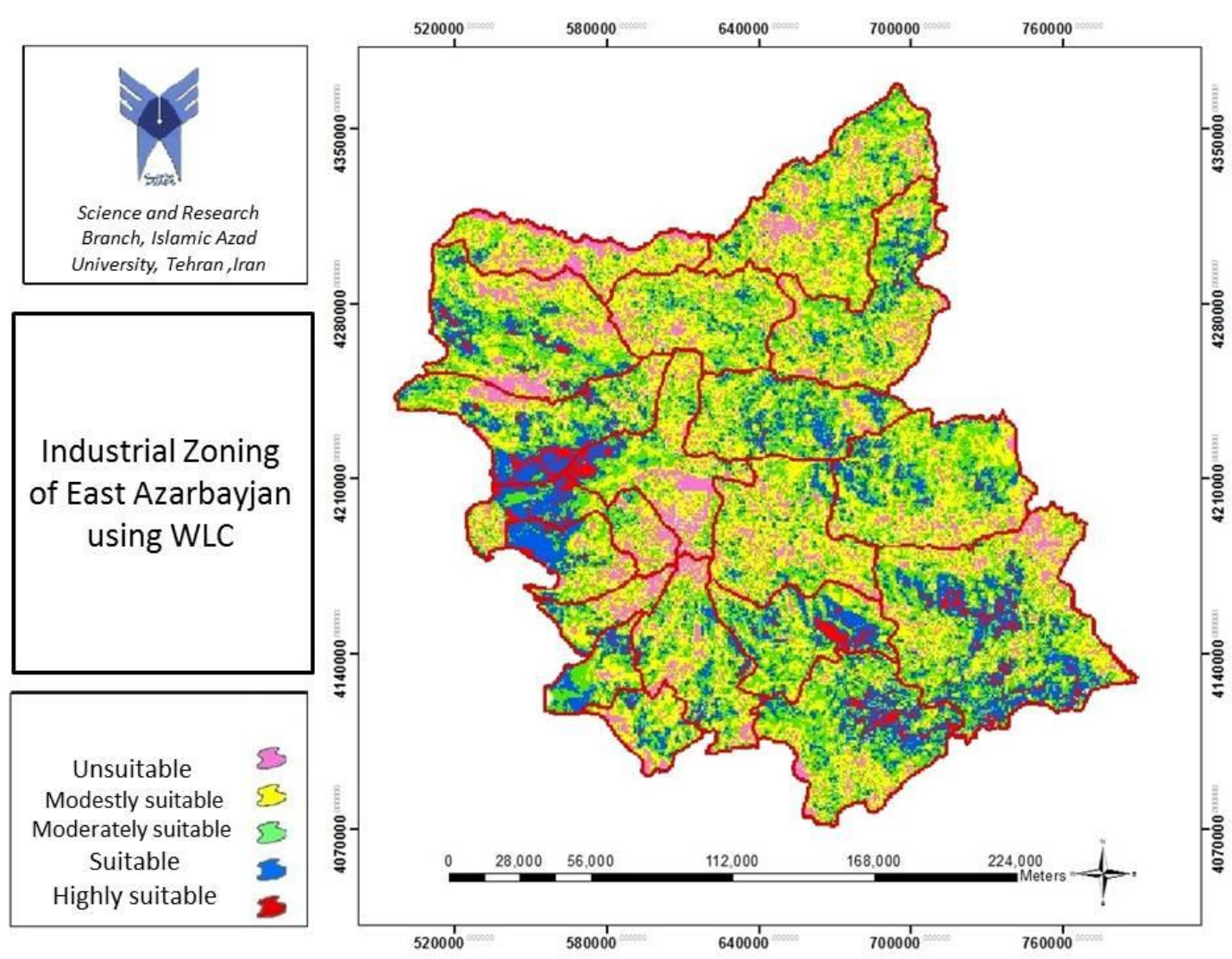

Figure 2. Industrial zoning of East Azerbaijan using WLC. Based on this method, after weighing of layers and summing of 22 criterial for industrial zoning, 119167 and $751156 \mathrm{ha}$

lands were respectively identified as highly suitable and suitable areas for industrial establishment. This mostly included districts of Myaneh, Shabestar and Charoymagh. In addition, this method suggested that more of province had weak potential for industrial establishment that were located in Kaleybar and Jolfa.

With the greater weight of human related parameters (e.g., road, the already present industries, power transfer lines) and the smaller weight of ecological parameters (e.g., slope, height, erosion) in TOPSIS, the total areas decided to be highly suitable and suitable for industrialization were lower in TOPSIS compared to other two evaluation methods. In TOPSIS vs. WLC and SAW models, the nonecological parameters related the current human uses of landscape received greater weight in the evaluation process. Thus, because of the vast regions of the province with such nonecological human related properties, the total area calculated to be unsuitable for industrialization was greater in TOPSIS vs. WLC and SAW methods.

This study for the first time establishes land zoning for industrialization in East Azerbaijan, an ecologically and economically important province in northwest of Iran. In addition, the findings of this research provide comparative evidence on industrial expansion capacity of East Azerbaijan among three global evaluation models of 
TOPSIS, WLC (combined Fuzzy and AHP models) and SAW. The multicriteria weighting and evaluation methods based on ecological and socioeconomical parameters have been successfully used to optimize land site selection for industrialization in China (Jiang, 2007). Comparing Fuzzy and Boolian evaluation models for industrial land zoning in Iran, Khorasani et al. (2004) and Mahmoodi (2007) found that Fuzzy method proved more suitable because of the quantitative and continuous nature of its evaluation scale. The Boolian method, in contrast, is a discrete evaluation model that reports merely whether a given site is suitable or otherwise unsuitable for selection, but it cannot continuously score how suitable or unsuitable the site is (Raeesi, 2011).
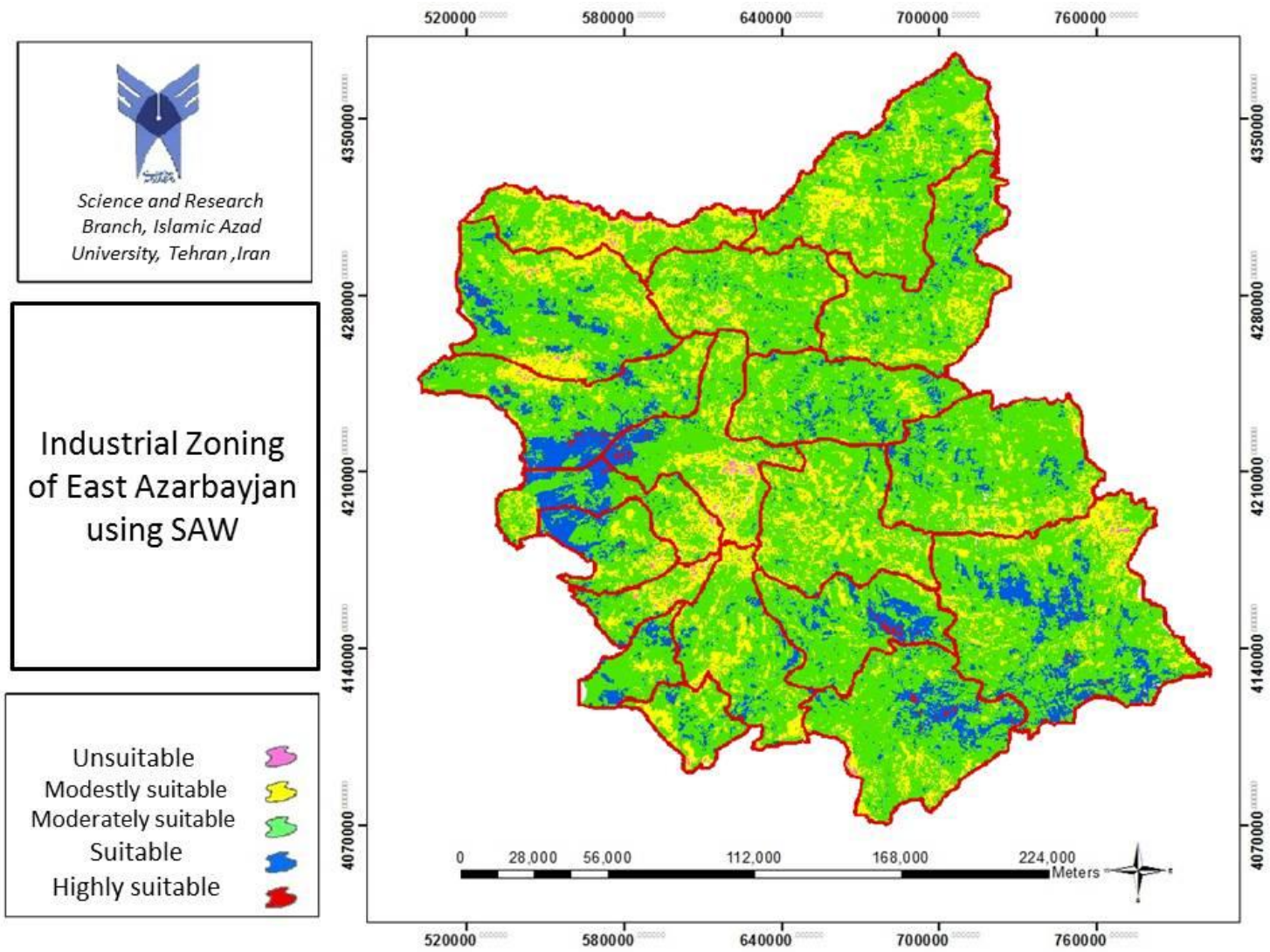

Figure 3. Industrial zoning of East Azerbaijan using SAW. After weighing of layers and summing of 22 criteria for industrial zoning, 10149 and 454494 ha lands were respectively identified as highly suitable and suitable areas for industrial establishment. This mostly included districts of Hashtrood, Myaneh, Shabestar and Charoymagh. This method also suggested that greater provincial areas were identified as having weak industrial potential that were located in Jolfa and Tabriz.

The TOPSIS method along with the AHP has been effectively used in different selection programs (Alavi and Alinejad-Rokny, 2011). As demonstrated in the current study for industrial site selection, the TOPSIS has been reported to be a highly flexible, precise and realistic method in grading plant species for mine restructuring and in ranking land sites for dairy manufacturing (Alavi and Alinejad-Rokny, 2011; Mokhtarian and Hadi-Vencheh, 2012). Since the criteria adopted for industrialization 
capacity assessment are of varying significance in land site selection, the present study utilized three different major evaluation methods to obtain comparative insights into zoning programs to help optimize future decision and policy making.
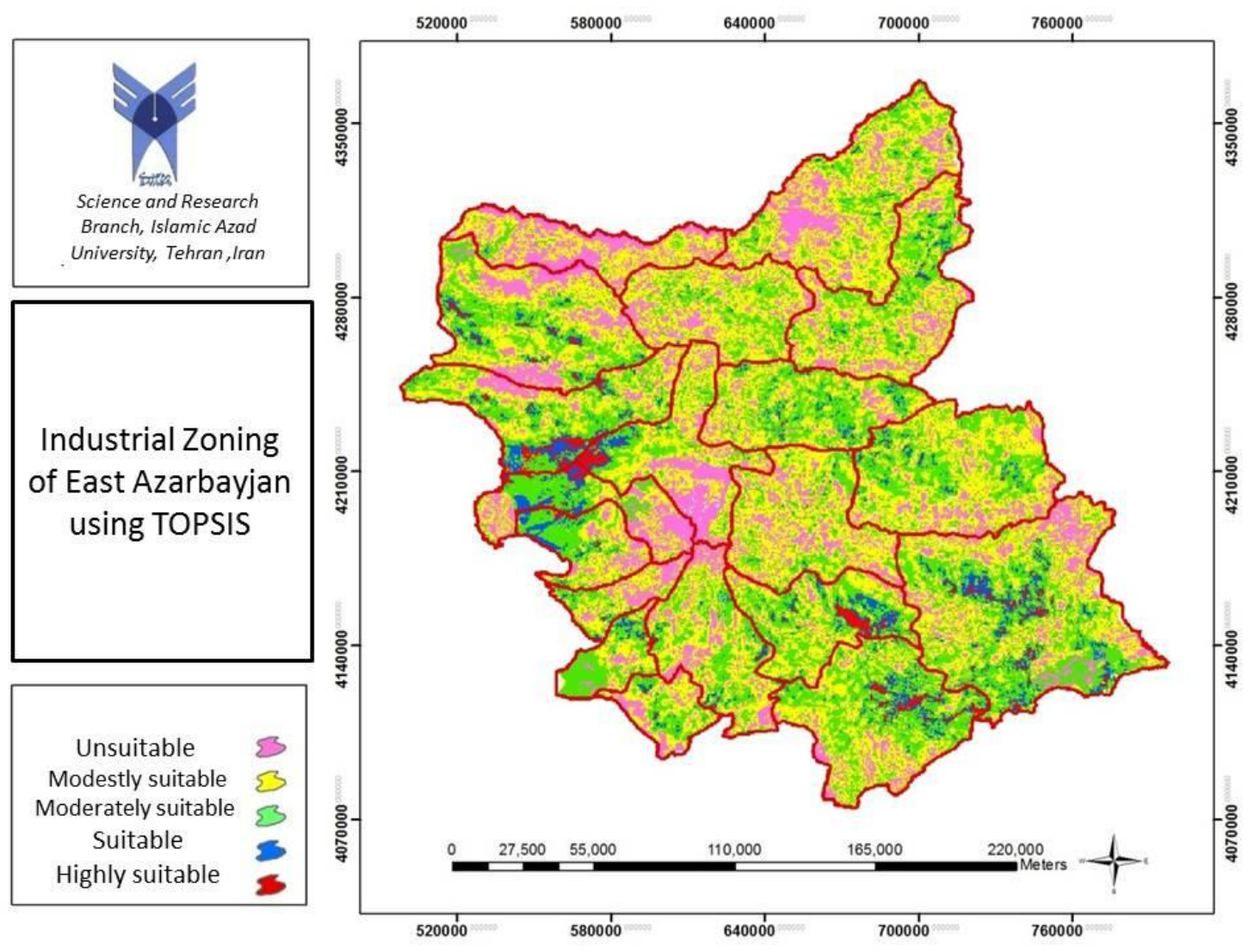

Figure 4. Industrial zoning of East Azerbaijan using TOPSIS. After weighing of layers and summing of 22 criteria for industrial zoning, 69119 and 200086 ha lands were respectively identified as highly suitable and suitable zones for industrial establishment. These zones were mostly located in districts of Shabestar, Myaneh and Charoymagh. This method also suggested that more of province had less suitable area for industrial establishment that were located in Kaleybar and Jolfa.

\section{Conclusions}

The multicriteria evaluation methods of WLC, TOPSIS and SAW enabled decision making on site selection for industrialization in East Azerbaijan based on different quantitative and qualitative environmental criteria and their relative importance. Because of the higher preference of nonecological parameters (related to human activity) modeled for industrial zoning by TOPSIS method, the total area with suitable industrialization capacity was found to be lower in TOPSIS vs. WLC and SAW. However, despite the differences of the evaluation methods in calculating the total land area with suitable industrialization capacity, the areas were overlapped among the methods. Miyaneh, Shabestar and Charoymagh were found to be the most capable regions of East Azerbaijan for industrialization. This information can be most effectively utilized in prospective policy and decision making for the provincial industrial expansion programs. 
Acknowledgements. Islamic Azad University (Tehran's Science \& Research, Tabriz, Qazvin and Jolfa Branches) and the Ministry of Science, Research and Technology are thankfully acknowledged for supporting this research program.

\section{REFERENCES}

[1] Alavi, I., Alinejad-Rokny, H. (2011): Comparison of Fuzzy AHP and Fuzzy TOPSIS Methods for Plant Species Selection (Case study: Reclamation Plan of Sungun Copper Mine; Iran. - Aust. J. Basic Appl. Sci. 5 (12): 1104-1113.

[2] Ali Zadeh, M., Ngah, I., Shahabi, H., Ali Zadeh, E. (2013): Evaluating AHP and WLC Methods in Site Selection of Waste Landfill (Case Study: Amol, North of Iran). - J. Basic Appl. Sci. Res. 3(5): 83-88.

[3] Aryanezhad, Mir. B., Tarokh, M. J.,Mokhtarian, M. N., Zaheri, F. (2011): A Fuzzy TOPSIS Method Based on Left and Right Scores. - International Journal of Industrial Engineering \& Production Research 22 (1): 51-62.

[4] Atthiawong, W., MacCarthy, B. (2002): An application of analytical hierarchy process to international location decision making. 7th Cambridge Research Symposium on International Manufacturing, Centre for International Manufacturing, Cambridge University.

[5] Bellman, R. E., Zadeh, L. A. (1977): Local and fuzzy logics. -In: Dunn, J. M., Epstein, G. (eds) Modern uses ofmultiple-valued logic. Kluwer, Boston, pp. 158-165.

[6] Burrough, P.A. (1990): Methods of Spatial Analysis in GIS. - International Journal of Geographic Information Systems 4: 221-223.

[7] Chang, H-K., Liou, J-C., Chen, W. W. (2012): Protection Priority in the Coastal Environment Using a Hybrid AHP-TOPSIS Method on the Miaoli Coast, Taiwan. Journal of Coastal Research, West Palm Beach, Florida 28(2): 369-374.

[8] Chen, C.T. (2000): Extensions of the TOPSIS for group decision making under fuzzy environment. - Fuzzy Sets Systems 114: 1-9.

[9] Church, R. (2002): Geographic information systems and Location science. -Computer \& Operation Research 29: 541-562.

[10] Dudukovic, J., Stanojevic, M., Vranes, S. (2005): Decision Aid for Sustainable Industrial Siting. - IEEE Serbia \& Montenegro 2(3): 22-24.

[11] Eastman, J.R. (1997): IDRISI for Windows users guide.Version 3.2, Clark Labs for cartographic technology and Geographic Analysis. - Clark University.

[12] Eldin, N. N., Eldrandaly, K. A. (2004): A Computer-aided system for site selection of major capital investments. 1st ASCAAD International Conference, e-Design in Architecture, Dhahran, Saudi Arabia.

[13] Eldrandaly, K., Eldin, N., Sui, D. (2003): A COM-based Spatial Decision Support System for Industrial Site Selection. - Journal of Geographic Information and Decision Analysis 7(2): $72-92$.

[14] Environmental Protection Agency. (2011). Laws site selection of industry in Iran, Publications of the Environmental Protection Agency.

[15] EPA. (1999): Guidelines On Sustainable Industrial Zone/Estate.

[16] Geneletti, D.,Van Duren, I. (2008): Protected Area Zoning for Conservation and Use: A Combination of Spatial Multicriteria and Multiobjective Evaluation, Landscape and Urban Planning 85: 97-110. 
[17] GIS Application: Environment: Scope of usage/implementation of Zoning Atlas results. www.gisdevelopment.net/application/environment/pp/envp0002.htm. Access date: Nov 20, 2016

[18] Guidelines for Establishment and Utilization of Food Production and Packaging Units (GEUFP). (2007): The Ministry of Health, Treatment and Medical Education, Food and Drug Deputy, Tehran, Iran.

[19] Guidelines for siting of Industry, www.wii.gov.in/eianew/eia/database/guidelines/siting1.htm. Access date: Nov. 15, 2016.

[20] Gupta, J.P. (2005): Land use planning in India. - Journal of Hazerdous Materials,Science Direct, Kanpur,India 130(3): 300-306.

[21] Hosseini, S.M., Monavvari, S.M., Khorshiddoost, A.M., Rastamzadeh, H., Naghdi, F., Ranjbar, G., NasirAhmadi, K. (2009): Ecological Capability Assessment of Tabriz Suburb, Iran, for Urban Development using Multi Criteria Evaluation Approach. En: Revista de Urbanismo. №21, Santiago de Chile, publicacion electronic editadapor el Departmento de Urbanismo, F.A.U. de la Universidad de Chile, I.S.SN. 0717-5051. http://revistaurbanismo.uchile.cl/CDA/urb completa/urb21Hosseini 001.html.

[22] Jiang, H., Eastman, J. R. (2000): Application of fuzzy measures in multi-criteria evaluation in GIS. International Journal of Geographical Information Science 14(2): 173-184.

[23] Jiang, J. (2007): Analysis of the Suitable and Low-Cost Sites for Industrial Land Using Multi Criteria Evaluation: A Case of Panzhihua, China. Master's of Science Thesis in Geoinformatics, School of Architecture and the Built Environment, Stockholm, Sweden.

[24] Jozi, S., Saffariyan, Sh. (2011): Environmental risk analysis Abadan gas station by using TOPSIS. - Journal of Environmental Studies 37(58): 53-66.

[25] Kazemi Rad, L., Ghamgosar, M., Haghyghy, M. (2012): Multicriteria Decision Making Based on TOPSIS Method in Drought Zoning: A Case Study of Gilan Province. World Applied Programming 2(2): 81-87.

[26] Khorasani, N., Shokraii, A., Mehrdadi, N., Darvishsefat, A. (2005): Environmental studies in order to site selections for landfill:case study: Sari,Iran. - Iranian Journal of Natural Resources 57: 275-284.(persian).

[27] Khorshiddoost, A.M., Rostamzadeh, H., Roostaei, Sh., Mohammadzadeh, R., FallahNejad, H., Khalkhali, M., Jam Kasra, M., Naghdi, F., Khoshdel, K., Mokhtarea, H., Soleymani, R., Azer, A. (2007): The Basic Design of the East Azerbaijan Province Preparation.

[28] Lee, G., Jun, K-S., Chung, E-S. (2013): Integrated multi-criteria flood vulnerability approach using fuzzy TOPSIS and Delphi technique. - Natural Hazards and Earth System Sciences 13: 1293-1312.

[29] Mahmoodi, M. (2007): Introduction and review the Advantages and Disadvantages of integrated models (Boolean logic, overlay map and fuzzy logic models) in GIS. Conference Urban GIS, Amol, Iran.(persian).

[30] Makhdoom, M. (2004): Environmental assessment and planning, geographic information systems (GIS). - Tehran University.

[31] Malczewski, J. (2006): Ordered Weighted Averagin with Fuzzy Quantifiers: GIS- based Multicriteria Evaluation for Land- use SuitabilityAnalysis. - International Journal of Applied Earth Observation and Geoinformation 8: 270-277.

[32] Mokhtarian, M.N., Hadi-Vencheh, A. (2012): A new fuzzy TOPSIS method based on left and right scores.An application for determining an industrial zone for dairy products factory. - Applied Soft Computing 12: 2496-2505. 
[33] Monavvari, S.M., Hosseini, S. M., Gharagozlu, A., Naghdi, F. (2013): Industrial developing in the East Azerbaijan according to the Ecological potential evaluation, Study area; North-West of Iran, Azerbaijan Province. - Journal of Applied RS and GIS Techniques in Natural Resource Science, Islamic Azad University of Bushehr (persian).

[34] Naghdi, F., Hosseini, S. M., Sadr, Sh. (2011): Ecological Capability Assessment of Tabriz Suburb, Iran for Urban Development. - Journal of Applied RS and GIS Techniques in Natural Resource Science 5: 91-99.(persian).

[35] Naghdi, F., Nikkhah, A. (2014): East Azerbaijan's Eco-Environmental Potential for Industrialization: Functional Systems Analysis Models. - Turkish Journal of Science \& Technology 9 (2): 135-139.

[36] Parhizgar, A., Ghafari Gilandeh, A. (2006): Geographic Information System and Multi Criteria Decision Analysis. - Samt Publication, Tehran, Iran. (in Persian)

[37] Raeesi, M., Safianian, A. (2011): Industrial Site Selection by GIS in Isfahan, Iran. Proceedings of The 19th International Conference on GeoInformatics.

[38] Raghu Babu, N. (2002): Scope of usage/implementation of "Zoning Atlas"results.Environmental Engineer, Central Pollution Control Board. http://www.gisdevelopment.net/application/environment/pp. nvp0002.htm.

[39] Ranjbar, G.R., Naghdi, F. (2013): Ecological Capability Assessment of Agricultural Lands in Marand Township Based on Multi Criteria Evaluation. - J. Environ. Sci. Technol. 15 (3): 112-116.

[40] Ruiz Puente, C., Diego, M., Ortiz, J., Hernando, M., Hernaez, P. (2007): The Development of a New Methodology Based on GIS and Fuzzy Logic to Locate Sustainable Industrial Areas. 10th AGILE International Conference on Geographic Information, Science Aalborg University, Denmark.

[41] Statistical Yearbook of East Azerbaijan., Governor's Office of Planning and Statistics Department of the East Azerbaijan Province, 2006.

[42] Store, R. (2009): Sustainable Locating of Different Forest Uses. - Land Use Policy 26(3): 610-618.

[43] Sui, D. Z. (1999): A Fuzzy GIS Modeling Approach for Urban Land Evaluation. Computer, Environment, and Urban Systems 16: 101-108.

[44] UNEP. (1997): The Environmental Management Of Industrial Estates.www.unep.fr/pc/ind- estates. Industrial Park Site Selection.http://info.wlu.ca/ wwwgeog/special/geomatics/pdf/industrial_selection.pdf.

[45] Urban Planning \& Architecture Research Center of Iran(UP\&ARCI). (2000): Initial Studies and AssigningStrategy for Database Formation. Project for establishing the geographic information databases of development plans, Tehran (persian).

[46] Wang, Y.M., Elhag, T.M.S. (2006): Fuzzy TOPSIS method based on alpha level sets with an applicationto bridge risk assessment. - Expert Syst. Application 31: 309-319.

[47] Yayla, Y., Yildiz, A., Özbek, A. (2012): Fuzzy TOPSIS Method in Supplier Selection and Application in the Garment Industry. - Fibres and Textiles in Eastern Europe 20(4): 20-23.

[48] Yu,V.F., Hu, K.J. (2010): An integrated fuzzy multi-criteria approach for the performance evaluation of multiple manufacturing plants. - Computers and Industrial Engineering 58: 269-277.

[49] Zadeh, L.A. (1975): The concept of a linguistic variable and its application to approximate reasoning-I. - Inf. Science 8: 199-249. 